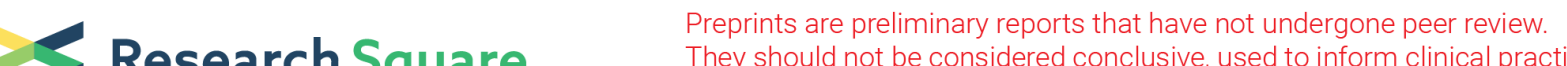 $\begin{array}{ll}\text { Research Square } & \text { They should not be considered conclusive, used to inform clinical practice, } \\ \text { or referenced by the media as validated information. }\end{array}$
}

\section{Patient's perspective regarding the elective surgical procedure during Covid 19 pandemic.}

\section{Dr. Mayank Badkur ( $\nabla$ drmayankbadkur@gmail.com )}

All India Institute of Medical Sciences Jodhpur Rajasthan India https://orcid.org/0000-0002-78508088

\section{Dr Ashok Puranik}

All India Institute of Medical Sciences Jodhpur Rajasthan India https://orcid.org/0000-0002-94901269

\section{Dr Naveen Sharma}

All India Institute of Medical Sciences Jodhpur Rajasthan India https://orcid.org/0000-0003-20677329

\section{Dr. Suruthi Baskaran}

All India Institute of Medical Sciences Jodhpur Rajasthan India https://orcid.org/0000-0002-82359767

\section{Research Article}

Keywords: Covid-19, Pandemic, Elective surgery, Patient's perspective, Wait and watch policy, Telemedicine

Posted Date: August 2nd, 2020

DOI: https://doi.org/10.21203/rs.3.rs-51361/v1

License: (c) (i) This work is licensed under a Creative Commons Attribution 4.0 International License. Read Full License 


\section{Abstract}

Introduction: The ongoing Covid-19 pandemic and the subsequent nationwide lockdown, has impacted all aspects of society including medical profession. In hospitals, the focus has mainly shifted to prevention and treatment of Covid-19 infection. Owing to this, all elective surgeries were postponed and only emergent surgeries were performed. This has affected the patients differently depending on the progression of disease and development of complications.

Materials and Methods: A well-structured telephonic scripted questionnaire was administered to all patients who were given appointment for any elective surgery. Data was collected regarding the status of disease including complications and the patient's perspective on method of treatment. Patients who developed complications or underwent emergency surgery or surgery elsewhere were excluded.

Results: The male to female ratio was 2.3:1. Mean age of patients was 41.16 years. A total of 86 patients were included in the study. Almost all (98.8\%) were aware that the lockdown and withholding of elective surgeries was to prevent spread of coronavirus infection. Among 34 patients with complications, $88.2 \%$ were willing to undergo surgical procedure and $73.5 \%$ were willing to visit hospital within a week or two. Among patients without complications, $71.2 \%$ were willing to continue treatment on wait and watch policy, for a period of 2 months or more (45.7\%). $93.5 \%$ of patients avoided visit to hospital due to risk of infection.

Discussion: Patient's attitude towards the choice of treatment (wait and watch Vs surgery) mainly depended on the progression of disease. It is critical, during these tough times of Covid-19 pandemic, that risks are weighed against benefits to decide the line of management for patients waiting for elective surgeries.

\section{Introduction}

On 31st January 2020, World Health Organisation (WHO) declared the 2019 - 20 COVID -19 outbreaks as a Public Health Emergency of International Concern (PHEIC) and on 11th March 2020, it was announced as an epidemic [1]. In India, the first case of COVID - 19 was reported on 30th January 2020 [2]. The Prime minister of India implored the nation to observe Janata Curfew on 19th March 2020 to sensitize the community and announced a nationwide lockdown thereafter to reduce the spread of COVID - 19. The Government of India is tirelessly endeavouring to spread awareness amongst the general population about the various ways in which corona virus can be contracted and transmitted.

The ongoing COVID-19 pandemic and the consequent nationwide lockdown, has impacted all aspects of society including medical profession. In hospitals, the main focus was shifted to treating the deadly Corona virus. Elective surgical procedures, as a result, were being postponed in all hospitals, primarily to save the patients from possible cross-infection from COVID-19 virus and also to utilise the workforce and 
resources to comply with the unique need of the time. In our institute, Department of General Surgery had to postpone most of the elective procedures. It is known that though there are certain diseases which require elective surgical intervention, they can be managed by wait and watch policy. However, these elective surgical procedures cannot be postponed indefinitely. Benign diseases can develop complications or their severity/grade can increase with time and patient's morbidity and outcome can be affected severely, even leading to mortality. On the other hand, poor outcomes are also reported among the patients who undergo surgical procedures during the COVID 19 pandemic and hospitals can be a potential area to catch the viral infection in these times. All these factor complicate the judgment to proceed for surgery for benign disease. The line between risk and benefit is thin and patient's perspective in this delicate decision has to be weighed.

Being an esteemed institute nationally, the waiting list of patients who required elective surgeries for benign diseases was long and appointments were given up to 2 months ahead. In view of extended lockdown, telemedicine consultation was started and this gave us the unique opportunity to telecommunicate with the patients to understand their suffering, their level of awareness and their attitude towards the proposed treatment in view of COVID- 19 pandemic.

\section{Materials And Methods}

After approval from the Institutional Ethics Committee (IEC), a telephonic interview-based survey was done among the patients who were given appointment for elective surgical treatment of their benign diseases in the Department of General Surgery, but could not undergo the procedure because of lockdown. A well designed telephonic scripted questionnaire was used to collect the data. All patients, who were given the appointment for any elective surgery for benign conditions were included in the study. During the interview, patients were asked about the status of their disease and their complaints were evaluated. Patients who took surgical treatment elsewhere, developed any complications or require emergency surgery were excluded from the study and appropriate treatment advice were given to them. Collected data was entered in MS Office Excel spreadsheet and analysis was done using SPSS.

\section{Results}

Among these patients, male and female ratio was 2.3:1. The mean age of patients was 41.16 years. The common diagnoses of patients waiting for surgery included carcinoma breast (2.8\%), cholelithiasis (13.0\%), epigastric hernia (3.7\%), fissure in ano (1.9\%), fistula in ano $(16.7 \%)$, haemorrhoids $(3.7 \%)$, inguinal hernia (30.6\%), periumbilical hernia (0.9\%), Phyllodes tumour (3.7\%), pilonidal sinus $(4.6 \%)$, pleomorphic adenoma of parotid gland $(0.9 \%)$, soft tissue tumour $(2.8 \%)$, colloid goitre of thyroid $(0.9 \%)$, umbilical hernia $(0.9 \%)$, undescended testis $(0.9 \%)$, varicocele $(0.9 \%)$, varicose vein $(11.1 \%)$. Patients with carcinoma breast and Phyllodes tumour were called on priority and further management was done.

Total 108 patients were waiting for their surgery when lockdown started on 23 March 2020. After IEC approval, patients were communicated telephonically. Six (5.6\%) patients who did not pick up the phone 
call, and seven (6.5\%) patients who underwent surgery for their illness elsewhere were excluded. The remaining 95 patients did not complain of any new disease other than their previous illness but $2(1.9 \%)$ patients were found to be in isolation because of their contact history. These 2 patients were excluded from the study. 41 (43.2\%) patients reported some new changes in their disease and 7 (6.5\%) out of these 41 patients were found to develop complications and immediately called for emergency treatment. All these 7 patients were also excluded from the study. The remaining $86(79.6 \%)$ patients were interviewed to collect data. All patients were aware of the COVID 19 virus infection and its mode of transmission. Also $100 \%$ of the patients were aware of the nature of progression of their surgical disease and the complications which could arise.

Almost all (98.8\%) the patients were aware about the lockdown and withholding of elective surgeries. They knew that it was done to limit the social interaction and to prevent the spread of virus infection. Of the 34 patients who were having new complaints/ complications, $88.2 \%$ were willing to undergo surgical procedure and $73.5 \%$ were willing to come to hospital for the surgery in within the same or next week. This was significantly higher than those who did not develop any new complaint/ complication in whom $50 \%$ were willing to undergo surgical procedure, only $38.5 \%$ agreed to come to hospital during this period and $71.2 \%$ of these were willing to continue the treatment on wait and watch policy. (Table I)

Among patients who were comfortable to continue their treatment on wait and watch policy, a maximum of $45.7 \%$ of patients wanted to wait for more than 2 months before the proposed treatment. A significantly higher proportion of these patients (93.5\%) wanted to avoid the hospital visit and $93.3 \%$ were afraid of it because of the infection. (Table II \& Table III)

When questioned if they thought that they would contract the virus infection in the hospital, only $9.3 \%$ said "no" whereas $70.9 \%$ patients were sceptical and said "may be" and 19.8\% were certain of the possibility.

\section{Discussion}

The coronavirus disease outbreak started on December 31, 2019 when the Wuhan Municipal Health Commission reported 27 cases of atypical pneumonia caused by virus "SARS-CoV-2" [3]. On February 11, 2020, the World Health Organization named this disease as COVID-19 [4]. India announced its first case on 30th January 2020 and since then, Indian health system is continually trying to tackle this unique yet arduous crisis. The Indian Government has worked extraordinarily to contain this infection and to spread awareness among the people. Policies about the functioning of hospital were designed in consultation with Indian Council of Medical Research (ICMR) and various SOPs were formulated to maximise the use of available resources.

India is one of the most densely populated countries in the world and this directly poses its health system with many challenges. The vulnerable patient population with surgical diseases can be broadly grouped into three categories, COVID positive patients, COVID negative emergency patients and COVID negative general patients. Where all the arrangements were focused to deal with COVID positive patients and 
COVID negative emergency patients, COVID negative general patients were mainly provided with alternative options to continue the treatment like telemedicine. In this group, patients who were planned for their elective surgeries were most affected because of the postponement of elective surgeries. On March 20, the Central Government directed hospitals and medical institutions to postpone non-essential elective surgeries up to March 31 and this was to be reviewed "as per evolving situation" [5]. According to a report published in the British Journal of Surgery on May $12^{\text {th }}, 28.4$ million elective surgeries were cancelled or postponed during the "12 weeks of peak disruption" [6]. In India, this number was expected to be 48,728 per week and about 585,000 over 12 weeks period [5]. Where all agencies were planning to provide the maximum benefit to the patients, knowing the perspective of these stakeholders (patients) is important to design appropriate strategies.

In this study, our main focus was to understand the suffering of this group of patients and to understand the cause of their concern. We found out that $6.5 \%$ patients developed complication. This fact is alarming that more and more such patients will develop complication or progressive disease and this will increase their morbidity and mortality.

Most of the study population was aware of COVID 19 disease and its mode of transmission. A crosssectional study among general public also showed similar results [7]. Another study done by Roy $D$ also showed sufficient awareness among the general population [8]. They were also aware that the purpose of lockdown was to limit social interaction and to prevent virus infection. They were also aware about the postponement of elective surgeries. This showed that the government's strategies towards the spread of awareness through social media, newspaper and television shows were effective [7]. Also maximum patients were found to be aware of the progression of their disease and related complications which speaks about the importance of detailed counselling at the time of consultation.

Patient's attitude towards the choice of treatment was mostly dependent on the progression of their disease where patients with progressive disease were keen for treatment during current period. More than $50 \%$ patients wanted to continue their treatment on wait and watch policy. Patients were avoiding hospital visit and many of them were afraid of it because of the risk of infection. This information provides an insight about the impact of COVID 19 pandemic on patient's psyche and suggests the need for detailed discussion in view of COVID 19 to make a more patient-centric treatment decision regarding their surgical condition.

Maximum patients wanted to wait for at least 2 months or more. This was suggestive of the perception that this disease will be controlled within this time frame. Similarly, in another study, majority (93.02) of the respondents believed that COVID - 19 will be controlled successfully and have the confidence that our country can fully eradicate the virus as early as possible. This information lacks scientific evidence but shows the positive attitude of general public which is important in these troubled times [7]. Keeping a high morale is one thing and facing the reality is another, especially at the time of making a crucial decision about one's treatment. 
Therefore, General surgeons, because of the wide variety of procedures they perform, are uniquely affected and have to take extraordinary leadership roles which can balance these factors and maximise output. Following points can be considered.

- Interpreting the patient's need of treatment as "elective" or "non-essential" [9] unless the risks of the disease impose a potential risk, morbidity or organ failure [10].

- Rethinking how we care for our patients in a time of social distancing during the COVID-19 pandemic and recognizing the role of technology in certain aspects like teleconsultation. The fact remains that, in surgical practice, there is nothing more intimate than the customary patient-physician interaction [11].

- If a patient is being called for surgery, ensure proper measures to protect patient and healthcare workers form contracting the infection. Guidelines regarding this can be formed at the individual institutional level, in coordination with the local circumstances, local and national governing bodies [12].

- Patients on wait and watch list will form a backlog of those seeking surgeries as the outbreak abates 5 and these patients will become the part of the 'second and third waves' [13].

- Follow up these patients as regularly as possible in a timely fashion so that disease progression and complications can be addressed as early as possible.

- About 50 per cent of revenues for hospitals in normal business conditions is generated by elective surgeries. Industry body Medical Technology Association of India (MTal) requested the government's intervention to ensure that elective surgical procedures were resumed at the earliest. This is vital for the Indian health sector as a large number of patients are served by private hospitals but this should not be the only factor behind the delicate decision of surgery [10].

\section{Declarations}

Ethics approval: Research study was conducted after Institutional Ethics Committee approval

Consent to participate: Participants consent were obtained.

Funding: This is an intramural funded project by All Indian Institute of Medical Science Jodhpur, Rajasthan, India.

\section{Conflict of Interest statement \& Disclosure Statement:}

Dr. Mayank Badkur, Dr. Ashok Puranik, Dr. Naveen Sharma and Dr. Suruthi Baskaran have no conflicts of interest or financial ties to disclose.

Dr. Badkur has nothing to disclose.

Dr. Puranik has nothing to disclose. 
Dr. Sharma has nothing to disclose.

Dr. Baskaran has nothing to disclose.

Acknowledgments: We wants to acknowledge Dr. Akhil Goel for helping in statistical analysis for this study.

\section{References}

1. Coronavirus Disease (COVID-19) - events as they happen [Internet]. Who.int. 2020 [cited 2 July 2020]. Available from: https://www.who.int/emergencies/diseases/novel-coronavirus-2019/events-as-theyhappen\#: :text=The\%20outbreak\%20was\%20declared\%20a,on\%2030\%20January\%2020

2. Rawat, Mukesh (12 March 2020). "Coronavirus in India: Tracking country's first 50 COVID-19 cases; what numbers tell". India Today. Retrieved 12 March 2020.

3. Sohrabi C. •Alsafi Z. • O’Neill N. •et al. World Health Organization declares global emergency: a review of the 2019 novel coronavirus (COVID-19). Int J Surg. 2020; 76: 71-76

4. World Health Organization (WHO). Naming the coronavirus disease (COVID-19) and the virus that causes it. https://www.who.int/emergencies/diseases/novel-coronavirus-2019/technicalguidance/ naming-the-coronavirus-disease-(covid-2019)-and-the-virus-that-causes-it. Date accessed: March 16, 2020

5. Chaitanya Mallapur I, Chaitanya Mallapur I. Covid-19 held up 5.8 lakh elective surgeries in India. Here's why further delay should be avoided [Internet]. Scroll.in. 2020 [cited 3 June 2020]. Available from: https://scroll.in/article/963085/covid-19-held-up-5-8-lakh-elective-surgeries-in-india-heres-whyfurther-delay-should-be-avoided

6. Nepogodiev D, Bhangu A. Elective surgery cancellations due to the COVID-19 pandemic: global predictive modelling to inform surgical recovery plans. British Journal of Surgery. 2020;

7. Dr. T Shenbhaga Vadivu and Dr. P Annamuthu, "An Awareness and Perception of COVID -19 among General Public - A Cross Sectional Analysis", International Journal for Modern Trends in Science and Technology, Vol. 06, Issue 04, April 2020, pp.:49-53.

8. Roy D, Tripathy S, Kar S, Sharma N, Verma S, Kaushal V. Study of knowledge, attitude, anxiety \& perceived mental healthcare need in Indian population during COVID-19 pandemic. Asian Journal of Psychiatry. 2020;51:102083.

9. Paraiso M, Brown J, Abrão M, Dionisi H, Rosenfield R, Lee T et al. Surgical and Clinical Reactivation for Elective Procedures during the COVID Era: A Global Perspective. Journal of Minimally Invasive Gynecology. 2020;

10. Odisha..., industry, crisis..., mysteries', booked, Centre s et al. Resumption of elective surgeries required to soften COVID-19 blow to healthcare sector: Medical Technology Association of India [Internet]. Deccan Herald. 2020 [cited 3 June 2020]. Available from: 
https://www.deccanherald.com/national/resumption-of-elective-surgeries-required-to-soften-covid19-blow-to-healthcare-sector-medical-technology-association-of-india-842817.html

11. Vogler S, Lightner A. Rethinking how we care for our patients in a time of social distancing during the COVID-19 pandemic. British Journal of Surgery. 2020;

12. Diaz A et al., Elective surgery in the time of COVID-19, The American Journal of Surgery, https://doi.org/10.1016/j.amjsurg.2020.04.014

13. Mayol J, Fernández Pérez C. Elective surgery after the pandemic: waves beyond the horizon. British Journal of Surgery. 2020;.

\section{Tables}

Table I: Presence of new complaints/complication and treatment choice

\begin{tabular}{|c|c|c|c|}
\hline & $\begin{array}{l}\text { Presence of any new } \\
\text { complaints/complication } \\
(n=34)\end{array}$ & $\begin{array}{l}\text { Absence of any new } \\
\text { complaints/complication } \\
(n=52)\end{array}$ & $\begin{array}{l}\mathrm{P} \\
\text { value }\end{array}$ \\
\hline $\begin{array}{l}\text { Willing to undergo surgical } \\
\text { procedure that was advised } \\
\text { before }\end{array}$ & 30 (88.2\%) & $26(50.0 \%)$ & $<0.001$ \\
\hline $\begin{array}{l}\text { Willing to come to the } \\
\text { hospital for the surgery in this } \\
\text { or next week }\end{array}$ & 25 (73.5\%) & 20 (38.5\%) & $<0.001$ \\
\hline $\begin{array}{l}\text { Willing to continue the } \\
\text { treatment on wait and watch } \\
\text { policy }\end{array}$ & 9 (26.5\%) & 37 (71.2\%) & $<0.001$ \\
\hline
\end{tabular}

$p<0.001$ by Chi Square test. All $p$ values calculated using Chi square test. Figures in parentheses represent column-wise percentages.

\section{Table Il: Attitude regarding avoidance of hospital visit}




\begin{tabular}{|c|c|c|c|c|c|}
\hline & & $\begin{array}{l}\text { Willing to continue } \\
\text { the treatment on } \\
\text { wait and watch } \\
\text { policy }(n=46)\end{array}$ & $\begin{array}{l}\text { Not willing to continue } \\
\text { the treatment on wait } \\
\text { and watch policy } \\
(n=40)\end{array}$ & $\begin{array}{l}\text { Total } \\
\mathrm{N}=86\end{array}$ & P Value \\
\hline \multirow{4}{*}{$\begin{array}{l}\text { Duration for } \\
\text { which patients } \\
\text { want to wait } \\
\text { before surgery? }\end{array}$} & $\begin{array}{l}>1 \\
\text { month }\end{array}$ & $12(26.1 \%)$ & $1(2.5 \%)$ & \multirow[t]{4}{*}{86} & \multirow[t]{4}{*}{$\begin{array}{l}\text { Not } \\
\text { calculated }\end{array}$} \\
\hline & $\begin{array}{l}>2 \\
\text { month }\end{array}$ & $21(45.7 \%)$ & 0 & & \\
\hline & $\begin{array}{l}>6 \\
\text { month }\end{array}$ & $12(26.1 \%)$ & 0 & & \\
\hline & $\begin{array}{l}\text { No } \\
\text { waiting }\end{array}$ & $1(2.2 \%)$ & 39 (97.5\%) & & \\
\hline \multicolumn{2}{|c|}{$\begin{array}{l}\text { Patients who were avoiding } \\
\text { hospital visit }\end{array}$} & 43 (93.5\%) & $1(2.5 \%)$ & 44 & $<0.001$ \\
\hline \multicolumn{2}{|c|}{$\begin{array}{l}\text { Patients were avoiding } \\
\text { hospital visit because of } \\
\text { infection }\end{array}$} & 43 (93.5\%) & $11(27.5 \%)$ & 54 & $<0.001$ \\
\hline
\end{tabular}

$p<0.001$ by Chi Square test. All $p$ values calculated using Chi square test. Figures in parentheses represent column-wise percentages.

\section{Table III: Avoidance and fear among patients}

\begin{tabular}{|llll|}
\hline & Avoiding visit to hospital & Not avoiding visit to hospital & P value \\
\hline Afraid of hospital visit & $14(93.3 \%)$ & $30(42.3 \%)$ & $<0.001$ \\
\hline Not afraid of hospital visit & $1(6.7 \%)$ & $41(57.7 \%)$ & $<0.001$ \\
\hline
\end{tabular}

$p<0.001$ by Chi Square test. All $p$ values calculated using Chi square test. Figures in parentheses represent column-wise percentages. 